\title{
Comparative education in an age of competition and collaboration
}

\author{
Justin J. W. Powell \\ Institute of Education \& Society, University of Luxembourg, Esch-sur-Alzette, Luxembourg
}

\begin{abstract}
Comparative education relies on experiences, expertise, data, and criticism derived from multiple contexts and diverse levels to generate insights, facilitate understanding, and explain change. Marked by connectivity, our contemporary era vastly increases the (potential) diffusion of ideas essential for scientific advance. Three interlocking trends emphasise the growing relevance of comparative educational research. Firstly, competition has become more potent - among scholars, their organisations, and within as across countries. Secondly, educational studies, as science more generally, are increasingly conducted in collaboration - across disciplinary, cultural, linguistic, and organisational boundaries enhancing the potential for discovery while producing influential scholarship. Thirdly, while educational research and policymaking are increasingly comparative, comparative knowledge stores are often only selectively used. To counter such reductionism, indepth comparative institutional analysis across divides of academy, politics, and practice remain crucial. The multidisciplinary field must claim its relevance more persuasively, even as scholarly exchange, mobilities, and cultural knowledge endure as vital foundations.
\end{abstract}

\section{KEYWORDS}

Comparative education; competition; collaboration; ideas; diffusion; policy; comparative institutional analysis

\section{Introduction: comparative education between experience, exchange and evaluation}

Comparative education relies on experiences, expertise, data, and criticism derived from multiple contexts and diverse levels to generate insights, facilitate understanding, and explain change. We live in an age marked by extraordinary mobility, an encompassing Internet, and English as the increasingly-dominant scientific lingua franca. These phenomena extend our connectivity and vastly increase the (potential) diffusion of ideas - the essence of scientific advance - and policy learning, as challenging as it remains to adapt solutions found within complex institutional settings to others. Worldwide, institutions and organisations of education and science have dramatically expanded, becoming key sites of exchange and debate that are crucial for innovation. From international conference participation and academic exchange to sabbaticals and even careers abroad, individual spatial mobility has become a sine qua non of the (successful) scientific career (see Kim 2017). For comparative and international education, even more for 
intercultural studies, opportunities for learning, for networking, and for deeper understanding of other contexts remain vital, especially to unmask the taken-for-grantedness of educational structures, cultures, and practices. Yet technology-facilitated exchanges and evaluation challenge conventional channels of scholarly communication, reputation-building, and stratification.

Globally, three interlocking trends emphasise the enhanced relevance of comparative social science today, including comparative and international education. Firstly, competition has become more potent among scholars, their organisations, and across and within countries. Competition is exacerbated, manifest in the aggregated results of international large scale assessments (ILSAs), like PISA and PIAAC, in innumerable ratings and rankings of higher education organisations (that have led to 'ranking regimes' that influence knowledge production, see Normand 2016), and in benchmarks entire countries seek to achieve - at all scales (Espeland and Sauder 2016; Naidoo 2016; Brankovic, Ringel, and Werron 2018). More than ever, competition to win awareness, audience, and attention relies on explicit, public comparisons of various performances (Werron 2015). Organizations seeking legitimacy, whether for-profit or not-for-profit, as actors, themselves engage in and manage themselves in competition with generalised others (Hasse and Krücken 2013). Given continuous and world-spanning connectivity, peer review-based ratings of research quality are converted by for-profit media companies into rankings marketed globally for profit, affecting entire higher education systems, organisations, and organisational subunits (Marques and Powell 2019). Continuous research evaluation and policy-driven research programmes distribute competitive grants via peer review at various levels, making not only educational research funding much more competitive. Historically, the focus of comparative education has shifted from knowing the 'other' (1880s) and understanding the 'other' (1920s) to constructing the 'other' (1960s) to the contemporary measuring of the 'other' (Nóvoa and YarivMashal 2003, 424).

Secondly, educational research, and social and natural sciences more generally, have become much more collaborative (Aman and Botte 2017; Günes et al. 2017). This is reflected in the tremendous rise, across fields, of co-authored scientific contributions (Wagner 2005; Leahey 2016). As higher education and science expand, collaboration across disciplinary, cultural and linguistic, and institutional and organisational boundaries contributes to the 'pure exponential growth' in scientific publications worldwide across the sciences (Powell et al. 2017). However, distinct patterns of centre and periphery remain, and colonial legacies endure, as Europe and North America continue to lead in producing natural and social science research, with a more recent shift to East Asia (Mosbah-Natanson and Gingras 2014; Zhang, Powell, and Baker 2015). Such collaboration increases the diffusion of ideas - ideally understanding as well - not only enhancing the potential for discovery but also producing the most influential science.

Thirdly, heightened competition and collaboration require individual scholars to cultivate their skills to work interculturally and compare more explicitly than ever before. International research teams, with larger numbers of team members and broader in scope and scale, are challenged to successfully develop comparative and mixed-methods projects, which have grown more complex (see Kosmützky 2018). This is especially so to avoid misunderstandings and fully capture the essential characteristics of other times and places. 
Despite technological advances, this endeavour has become more challenging, as traditional area studies programmes, in the United States and beyond, struggle to maintain their government and foundation supports (Stevens, Miller-Idriss, and Shami 2018). Generally, American social sciences remain stubbornly parochial in the face of cultural diversity and massive global challenges (Kurzman 2017), largely ignoring the historic exchanges, intellectual and physical, across the Atlantic that enabled the development and differentiation of the social sciences (Fleck 2011).

Much is at stake as educational research and policymaking have become increasingly comparative - on the basis of innumerable, often reductionist, performance measures, myriad indicators, and formal evaluations (Powell et al. 2018). Now ubiquitous indicators, and the policy instruments based upon them, often make highly selective use of knowledge stores, even those collected for decades in comparative educational and social sciences that provide insights beyond evident similarities and obvious differences. Thus, comparative education, and especially historical studies of policy learning and issues of transfer and translation in a world of increasingly accessible data, have become more crucial. The constellation of issues with which the field must grapple may be found at the intersection of learning across borders, comparative methods, and 'epistemic governance' of education (Normand 2016), all shifting with powerful technologies of communication and data analysis (see, e.g. recent World Yearbooks of Education: Steiner-Khamsi and Waldow 2012; Fenwick, Mangez, and Ozga 2014; McLeod, Sobe, and Seddon 2018; Gorur, Sellar, and Steiner-Khamsi 2019). Here, the interlocking themes of competition, collaboration, and comparison will be discussed at the nexus of technological change, mobilities, academic languages and cultures as well as research policy and evaluation.

As competition and collaboration shape higher education and science, scholars in comparative and international education are especially well-positioned to leverage the discipline's theories and methods to explore and explain the potential of learning from others, reaching beyond area studies to explicit comparative analysis that reflects both the foundations of all social sciences and their inherent challenges (Schriewer 2006, 2012, 2016). Yet, the long-term institutionalisation of education and science systems implies path-dependent, incremental change that reflects institutional reproduction and gradual adjustment more so than revolutions, even if over the long-term such change may be transformative (see Mahoney and Thelen 2010). Gradual change, coupled with unanticipated and unintended consequences, often poses barriers to understanding and to the solving of (policy) problems endemic to education.

The approach taken here brings comparative institutional analysis to bear on such questions of persistence and change in institutions, organisational fields and forms, and organisations. Examples include the challenges of reducing exclusion (guaranteeing education for all) and achieving the human right to inclusive schooling to tenacious disparities in participation, achievement, and attainment across levels of education (e.g. Powell 2009; Artiles, Kozleski, and Waitoller 2015; Richardson and Powell 2011; Hadjar and Gross 2016). Furthermore, recent politics-driven limits placed on inter- and intra-regional migration flows, such as across the European Union, reduce the capacity for exchange and learning from diverse others, despite programmes to provide support for asylum-seekers (Streitwieser and Light 2018). Especially small states like Luxembourg, Qatar, and Singapore, with relatively limited domestic talent pools, rely on migration and mobility to establish and expand their higher education and science systems via brain circulation (Powell 2014; 
Streitwieser 2014; Ortiga et al. 2019). Global patterns and drivers of change on multiple levels must be contrasted with national, regional, and local persistence and specific barriers to the diffusion of ideas, standards, and policies.

\section{The diffusion of policy ideas, transfer, and inertia in education systems}

Ideas may be viewed as weapons in discursive battles, as in political science (Schmidt 2008), told as myths in sociological accounts (Meyer et al. 1997), or constructed as meta-ideas or travelling ideas that have the quality to 'build a bridge between the passing fashion and a lasting institution' (Czarniawska and Joerges 1996, 36). From the beginning, researchers in comparative and international education have focused on issues of the diffusion of educational concepts, whether relating to individual learners, curricula or settings. Core questions relate to the potential of improving education systems by understanding them better through comparison - or even emulating elements of other education systems deemed successful (Powell and Solga 2010). Educational transfer has been a continuous feature of comparative and international education, construed as a process in which a local problem is recognised, solutions to similar challenges found in other countries are identified, and these are imported and (more or less) adapted to the national or local context (Beech 2006). Works have examined these processes using concepts such as the processes of 'cross-national attraction' in policy (e.g. Phillips 2011), the 'politics of educational borrowing and lending' (e.g. Steiner-Khamsi and Waldow 2012) or 'international arguments' in education (e.g. Gonon 1998). The essence of the field has been distilled as 'unified around the objectives of understanding better the traditions of one's own system of education by studying those of others and assessing educational issues from a global perspective' (Cook, Hite, and Epstein 2004, 130).

To explain policy diffusion worldwide, Dobbin, Simmons, and Garrett (2007) distinguish between social constructivist theories that emphasise knowledge networks and the influence of international organisations; learning theories that point out experiential developmental processes within and between geographical units; competition theories that attend to the costs and benefits of policy choices and global exchange; and coercion theories that point to power differentials among nation states and institutions operating internationally. Thus, we must show how imitation or emulation influences (education) policy-making as well as understand why diffusion has been limited in temporal or spatial reach, related to whether mechanisms of diffusion are mimetic, normative or coercive (DiMaggio and Powell 1983; Scott 2014). While the contribution of neo-institutional theorising has been mainly to chart how legitimated organisational forms and practices have been successfully diffused and reproduced (Bromley and Meyer 2015), analyses of institutionalisation processes and institutional change (Schneiberg and Clemens 2006) and discourse (Schmidt 2008) have become increasingly central. Yet why do discursively successful models often fail to be (successfully) implemented elsewhere? This perspective examines not only diffusion and policy-making processes per se, but also the consequences and interplay of global, national, regional, and local levels in the conception and implementation of reforms - and the persistence and path dependent change in the complex structures of education and science systems controlled by multiple levels of governance (e.g. Powell 2009; Blanck, Edelstein, and 
Powell 2013; Biermann and Powell 2014). Recent studies of institutional change explore the diffusion and translation of ideas, concepts, standards, and policies as well as inertia as myriad change processes proceed - gradually - on different levels (Suárez and Bromley 2016; Powell [2011] 2016; Schriewer 2016).

In an increasingly globalised and interdependent world, long-term convergence may be expected and has been demonstrated, especially when it comes to educational discourses. Internationalisation and Europeanization have become favoured concepts in policy communities and rightfully have been increasingly examined to measure the influence on education of international organisations and supranational governments, such as the EU (e.g. Dale and Robertson 2009; Lawn and Grek 2012; Powell, Bernhard, and Graf 2012; Dobbins and Knill 2014). Yet despite the growing salience of global and regional levels, comparative institutional analyses question the ubiquity and speed of such often-discussed changes as they instead emphasise the mechanisms and concepts of evolutionary or gradual, incremental change as well as sustained national differences (e.g. Mahoney and Rueschemeyer 2003; Mahoney and Thelen 2010, 2015). Cross-national convergence theses need to be carefully tested, because the rhetoric of both policymaking and social science seems to outpace institutional and organisational change on lower levels. Thus, what appears as institutional convergence at first glance may well reveal profound differences upon closer examination that delves below the level of global or regional discourse (Powell et al. 2012; Dobbins and Knill 2014). In examining, what they call 'knowledge regimes' - consisting of communities of policy research organisations - Campbell and Pedersen (2014) emphasise the national origins of policy ideas and delve deeply into national cases to chart their production and dissemination as well as persistent substantive national differences.

Studies show that the diffusion of expectations, credentials, and structures in education has been worldwide (Meyer and Ramirez 2007; Baker 2014; Frank and Meyer 2020, in press). Yet this diffusion has led to diverse outcomes, depending on pre-existing national policies and institutionalisation pathways, as manifest in myriad educational fields. While education expansion since the Second World War has been witnessed everywhere as most of us now live in 'schooled societies' (Baker 2014), the worldwide diffusion of values and structures in education and science has not led to simple convergence, as transnational agenda-setting and rule-making often undergird instead of limit national policies (Krücken 2003; Campbell and Pedersen 2014). Indeed, even where some convergence is found, such as in higher education and vocational training systems in France and Germany, the movements have been neither simple nor unidirectional (Powell et al. 2012). When differentiating by level, the consequences of such large-scale and/or long-term shifts are often unanticipated or unintended. Institutional change resulting from international ideational and economic pressures as well as normative and regulative influences may well be consistent with national cultural and structural characteristics. And supranational governance has, thus far, only circumscribed control of education systems. Indeed, because ideas and policies 'morph as they move' (Cowen 2009, 315), such questions are among the most complex to answer conclusively. These demand significant synthesis of data sources and across methods and attention to operationalisation and harmonisation of data gathered in diverse settings - as well as considerable linguistic and cultural knowledge. This basis enables the distinguishing of sources and consequences of gradual change as well as the analysis of 
shifting relationships between organisational fields, whether special and inclusive education, vocational training and higher education, or disciplinary research and policy fields. Before discussing the implications of such trends of competition and collaboration on comparative education, in line with this special issue's focus on 'the comparative educationist as a foreigner' and contemporary scholars reflecting on the kinds of comparative education they do and why, I identify some biographical roots of my scholarship.

\section{On biographical roots of comparative education scholarship}

The above sketched approach taken in my neo-institutional comparative studies of education and science systems was enabled by multicultural and multilingual upbringing as well as years of study and research in multiple educational and scientific contexts, cultural and organisational. Here, I briefly reflect on biographical foundations and mobility effects on that comparative-historical sociological research on educational institutions and organisations, which requires deep linguistic and cultural knowledge for explicit, in-depth comparison. In theorising and analysing diffusion, institutional change, and path dependence in education and science systems, my comparative institutional approach weaves together insights from sociology, political science, and educational studies. Fluency in English and German and a multidisciplinary, liberal arts education enabled a career conducting comparative social science research in diverse internationalised organisations - from research universities in the US, Germany, the UK, and Luxembourg to key multidisciplinary research institutes in Germany. All provide(d) insights into the organisation of science, sustained learning opportunities, access to global networks as well as unparalleled scientific resources - brilliant mentors, peers, and students; well-funded libraries and access to leading databases; academic freedom to pursue research questions; and project management support to conduct complex comparative studies. Such privileged conditions provide a platform for long-term career development, most importantly communication and connections with others who encourage and challenge us to think both across borders and delve deeper into black boxes. Research collaborations with senior and junior colleagues and students from diverse backgrounds and theoretical as well as methodological skills have opened up otherwise less accessible avenues of scholarship. More than three dozen authorial partnerships have extended across disciplinary, methodological, generational, and cultural boundaries. This has greatly facilitated the range and depth of my scholarship in comparative and international education.

My comparative institutional analyses of education and science systems have focused on topics of global relevance, whether special and inclusive education, vocational training, and higher education and research policy. Yet the importance of and approaches to these themes varies considerably by place and disciplinary community. The United States, the country of my birth and primary socialisation, earlier and more forcefully embraced rights-based inclusive education and broad participation in an extraordinarily diverse and stratified higher education system. Growing up in the American South in the 1970s, I attended schools that had only recently been desegregated, racially. Children with disabilities would be the next group to be integrated in general public schools, which required similar societal and political struggle. Under protection from the Education of 
All Handicapped Children Act of 1975 (now: Individuals with Disabilites Education Act, IDEA), my twin brother Martin was among the first 'mainstreamed' children in Charlottesville, Virginia (Powell 2018), yet only after the local school district was forced to make necessary accommodations; he began elementary school several years later. Growing up acutely aware of stigmatisation and institutionalised discrimination shaped my understanding of social exclusion and inclusion and of institutional persistence and change in education. Germany, the country in which my academic career was shaped, provides a notable contrast. A pioneer in special education, it continues to segregate most pupils with special educational needs. Despite its class-based secondary schooling, its vocational training system of dual apprenticeship is hailed globally. If also the birthplace of the research university, it has a dual structure of research universities and universities of applied science with organisations relatively equal in status within these sectors. My first German university experience was as exchange student at the Ruprecht Karls University of Heidelberg (est. 1386), just after German reunification. The conditions for students, even within one of the oldest and most esteemed German universities, and the instruction methods were contrasts for me. On full scholarships, I had attended Woodberry Forest School (est. 1889) in Virginia and the Quaker liberal arts college Swarthmore (est. 1864) in Pennsylvania (Clark 1970), in which students resided together in a progressive learning community on a sylvan campus; the median class size was lower than twenty, not forty-plus; and interactions were mainly dialogic, with constructive questioning, less lecturing or sharp critique. The differences between the saxonic and teutonic intellectual styles (see Galtung 1981), with different emphases on theory or empirics as well as different styles of argumentation, are among the most challenging aspects of academic mobility - and of cross-cultural peer review and publication. Understanding of these different styles facilitates translation and publication; a key skill to transfer to the next generation of scholars in comparative education.

My understanding of substantial cultural differences - matched by disciplinary specifities - was facilitated by work after college at the New York-based Social Science Research Council (SSRC). There, I coordinated fellowship programmes, experienced multidisciplinary research planning and peer review from within a globalist grant-making organisation (see Lamont 2009), and built bridges between scholars from diverse countries and disciplines (see Stevens, Miller-Idriss, and Shami 2018; Kamola 2019). Thereafter, I entered the inaugural cohort of the 'Transatlantic Masters' (TAM) programme at the University of North Carolina at Chapel Hill, with partial funding from the European Commission, a major supporter of cross-border exchange and international student mobility (Powell and Finger 2013; Kmiotek-Meier, Karl, and Powell 2018). Moving to Berlin for the programme's European portion, I wrote my MA thesis in German - a comparative study of social science funding by the US National Science Foundation and the German Research Foundation (DFG) - at the Humboldt-Universität zu Berlin (est. 1810) (Powell 2000). Upon graduation, I joined the independent research group 'Ausbildingslosigkeit' on less-educated youth and lack of training, directed by Heike Solga (2005) at Berlin's Max Planck Institute for Educational Research. My dissertation Barriers to Inclusion, on the institutionalisation of special education (Powell [2011] 2016) analysed the structures and cultures of 'student disability' over the twentieth century in Germany and the US - and was among the first dissertations allowed to be written in English for a sociology doctorate from the Freie Universität Berlin (est. 1948). 
Thanks to my maternal grandparents in Germany, I learned German and how to cross cultural and generational boundaries. My BA, MA, and doctoral theses were German-American comparative analyses, built upon various phases of education and research in both countries, as student, doctoral candidate, and postdoctoral fellow. Further periods of study, research, and teaching at the Wisconsin-Madison, the LSE, and the Georgia Augusta University Göttingen, among others, have deepened my appreciation for similarities and differences in American, British, and German universities.

Since 2012, I have carried out research projects within the (inter)national University of Luxembourg (Powell 2013; Harmsen and Powell 2018). Especially Luxembourg, as a hyperdiverse society at the crossroads of the Germanophone and Francophone worlds and hosting a cosmopolitan EU capital city, presents a rich locale to conduct comparative research on diffusion and policy learning across borders and on multiple levels of analysis. Indeed, bolstered by unparalleled communication and mobility, our time should facilitate a new golden age for comparative education and social science more generally. With Europe's youngest national research university also multicultural and trilingual, the Grand Duchy provides a laboratory to study processes of Europeanization and internationalisation, institutional and organisational development, and intercultural communication (Meyer 2008; Powell 2014; see contributions in Margue 2013). Founded in 2003, the University of Luxembourg has achieved considerable success due in large measure to its global recruitment of faculty and staff who contribute their existing global networks (Powell and Dusdal 2017a, 2017b). Indeed, by design and parliamentary decree, Luxembourg has the highest rates of international student mobility worldwide (Kmiotek-Meier, Karl, and Powell 2018). Its high international co-authorship rates also confer tremendous advantages for in-depth comparative studies and the potential to bridge theoretical traditions in English, German, and French (Powell and Dusdal 2017a). Regardless of the selected site, comparative education demands investment in cultural knowledge and studies require sustained efforts to 'compare, compare, compare' (Cummings 1999).

\section{Influential comparisons, comparing influences: European advantages}

To provide further insights and ensure the influence of comparative education requires explicitly comparative research designs beyond the single case study and in-depth research beyond (and critiquing) reductionist ratings and rankings (Brankovic, Ringel, and Werron 2018). Achieving this potential requires intercultural collaboration in research and often challenging multilingual and multidisciplinary synthesis. Unlike the US research university context that reflects parochialism in US social science (Kurzman 2017; Stevens, Miller-Idriss, and Shami 2018), working in the diverse cultural context of Europe emphasises the necessity of comparative and multilevel studies that reflect its tremendous diversity of scientific communities. Europe also drives comparative research, due to the European Union's supranational governance and investments on collaborative and comparative studies; on the basis of dozens of countries, of varying size, in continuous dialogue over decades (and preceding centuries); and benefitting from local traditions as well as historical approaches that have been foundational for comparative education (Schriewer 2006). Given the age and embeddedness of extant institutions and organisations, with some universities surviving centuries and thus outlasting myriad political regimes, the Bologna process in higher education proffers an emergent European 
model in skill formation, significantly bolstered by state support for universities and international exchange (Powell, Bernhard, and Graf 2012; Powell and Finger 2013; Dakowska 2019). Current ideals, as well as the rates, of international mobility across Europe Erasmus exchanges have, in just a quarter-century, risen to around a quarter-million persons a year - demonstrate the systematic diffusion of ideas and values. This proceeds, as ever, via personal experiences. The ensuing translation and editing processes facilitate inter-sectoral circulation of organisational designs and templates, instruments, and reforms (Sahlin-Andersson 1996; Suárez and Bromley 2016).

European scholars in comparative education follow diverse approaches that reflect contrasting values, multiple methodologies, and disciplinary histories. Yet across these diverse fields, the rise of vast quantities of individual-level, often psychometric, data shifts attention away from historical as well as macro-level and meso-level studies that compare contextual conditions and organisational dimensions of education. Indeed, the splitting-off of 'empirical' educational research into its own organisational field poses a clear threat both to synthesis across levels of analysis and methodologies and to theoretical and methodological plurality (on Germany, see Zapp and Powell 2016, 2017). By contrast, mixedmethods studies that attempt to triangulate the results of qualitative and quantitative analyses and historical studies have considerably advanced, as have network analyses that emphasise cross-border interaction and facilitate analysis of research governance of and through networks (see Hollstein, Matiaske, and Schnapp 2017). More critically, many dimensions of educational processes defy measurement, because 'educational relationships that are social, emotional, epistemological, normative, political, cultural, and economic cannot be simply measured' (Unterhalter 2017, 2). Yet comparative education, when it utilises cutting-edge social scientific approaches - to conduct relational or longitudinal studies, for example - and shares its techniques and findings for understanding education, can claim to be a most vibrant social scientific discipline of relevance for the contemporary era. Tertiary educational participation continues to expand, even in those European countries with strong vocational education systems - the collective skills systems that provide attractive alternatives to higher education (Powell and Solga 2011; Powell and Trampusch 2012; Graf 2013; Bernhard 2017; Frank and Meyer 2020). Europe, with its diversity of languages and cultures, also benefits from government commitments to (higher) education and, also via European Union policies, to research - albeit with stratification visible at every level. The next section addresses how competition and collaboration in science has developed, reacting to diverse forces and conditions, with implications for comparative social sciences drawn.

\section{Comparison developing in an age of competition and collaboration}

The potential of contemporary science cannot be understood and the pathways to its further development charted without examining two contrasting concurrent trends rising competition and collaboration across and within nations: If countries continue to fund most scientific research, (international) collaborations among scientists across levels and teamwork in diverse types of research organisations have facilitated remarkable growth in knowledge production (Adams 2013; Powell, Baker, and Fernandez [2017] 2019). The future of (higher) education and science that must grapple with complex environmental and social problems now depends on how we (re)organise these fields to 
become more collaborative in the face of globalised competition between teams, organisations, and countries. For comparative social sciences, both risks and opportunities abound. If the strongest science countries and the most reputable organisations may crowd out diverse voices even more, increased emphasis on collaborations supports larger comparative projects impossible or difficult to conduct alone. Indeed, transnationalization (and regionalisation) of higher education and science challenge traditional nationfocused studies. The diffusion of worldwide ideas and norms in science is a powerful driver of global similarities, as no country can resist global standards (Drori et al. 2003). Higher education participation rates continue to climb, now reaching ever-larger proportions of each cohort in societies everywhere (Schofer and Meyer 2005; Frank and Meyer 2020). Scientization is significantly driven by the research universities that increasingly influence the design of reforms of schooling, policymaking activities, and economic development - by producing expertise via professionals and, ultimately, the occupations of the future (Baker 2014). Despite convergence pressures, directed by international organisations - extending in networks far beyond the big players of UNESCO, OECD, and World Bank (see Zapp and Ramirez 2019) - comparative institutional analyses show persistent differences in the structuring and capacity for innovation in higher education and science (Campbell and Pedersen 2014). At organisational form level, we find sustained, even increasing, significance of the research university in scientific production (Powell and Dusdal 2017a, 2017b; Dusdal 2018; Dusdal et al. in press).

While industry and science-producing organisational forms such as independent research institutes, government agencies, and academies, among others, contribute to advancing knowledge, we know too little about the conditions these forms, and organisational hybrids, provide - and how they utilise their networks, developing 'relational quality' to facilitate innovation (Dusdal, Oberg, and Powell 2019). Institutionally, university, industry, and government form the 'triple helix' of science production, with specific developments of these interinstitutional, boundary-spanning networks leading to different innovation dynamics (Leydesdorff and Etzkowitz 1998). In particular, education and science ministries in many countries and on multiple levels have reacted to the results of international large-scale assessments of student performance by reforming education systems and investing in certain types of educational research (Martens, Niemann, and Teltemann 2016). The 'global education industry,' based on diverse consulting, research, and policy activities, is no longer determined only by a few influential players, such as leading (I)NGOs, but rather by diverse actors that define and implement specific conceptualizations of 'good' education, increasingly viewed as a private good (Parreira do Amaral, Steiner-Khamsi, and Thompson 2019). In the global policy arena, organisations actively produce and utilise academic outputs to drive policy transfer and spur development, even when education statistics, such as aggregated PISA scores, have been misused to justify such economic policies despite their invalidity for this purpose (Komatsu and Rappleye 2017; see also Normand 2016).

Education was never only a state initiative, and comparative education and field work abroad in the social sciences have been significantly enabled by philanthropies - and massively affected by their redirection. As Kamola (2019) demonstrates, the SSRC shifted from area-based grant funding to 'global' programmes, reflecting the changing political economy of US higher education as much as scholarly debates emphasising transnational analysis. In the US, the largest philanthropic foundations, such as Carnegie, Ford, Mellon, 
and Rockefeller, have throughout their long histories targeted education programmes, and priviledged research universities that often bear their names. Such funding was essential to establish US dominance in many fields, even as more recent support of college and university alumni has become essential to counteract the state's retrenchment in higher education and thus maintain this position of intellectual power. More specifically, Takayama (2018) shows how the Rockefeller-funded International Institute at Teacher's College, Columbia University, became crucial to the global dissemination of American educational ideas and methods, thus exemplifying the politics of scientific knowledge a century ago for comparative and international education. As Manson $(2018,2)$ recounts, 'the substantial establishment of comparative education at universities in North America and parts of Western Europe after World War II (1945-70) shows the clear relationship between power and knowledge.' In Germany, foundations like Bertelsmann and Volkwagen similarly focus increasingly on educational matters, with the Hertie Stiftung even founding its own higher education organisation, Berlin's Hertie School of Governance (est. 2003), and Jacobs renaming the private university in Bremen Jacobs University (est. 2001). However, even these foundations' most influential programmes hardly substitute for the massive public support Germany's higher education and science organisations benefit from, even though university funding has not kept pace with the strongly rising student numbers, also due to nearly non-existent tuition fees (Powell and Solga 2011). Currently, both German and American education systems are further challenged by datafication and digitalisation of education (see Hartong 2019). Market-oriented (higher) education systems, notably the US and the UK, have experienced massive privatisation, as many governments reduce those investments that led to the initial flourishing of universities (Graf and Powell 2017). Contemporary tensions arise due to rising costs, exacerbated in times of mass status competition via higher education participation. The main driver of scientific capacity is the education and training of each generation of scientists poised to push the cutting edge, a continuous intergenerational process.

Factors, from research policy and funding instruments and system development to scientific communication, have also transformed the ways science is conducted and the scope and speed of knowledge diffusion around the world. If markets for scientific talent have always been wide, today they are nearly boundless, at least at the peaks and with the dominance of English as contemporary lingua franca. Elaborate migratory flows, massive government and philanthropic programmes, and everyday mobility enormously facilitate the exchange that leads to dense scientific networks, 'brain circulation', and the potential for collaboration on a vast scale (Sugimoto 2017; Jöns 2018). For example, the European Union's Erasmus programme or the US Fulbright Fellowships have enabled millions of students and faculty to visit other universities to broaden their horizons and explicitly gain knowledge and experience of another culture (Bhandari and Blumenthal 2011; Van Mol 2014).

Throughout history, large-scale migration flows, especially of elites, have led to the transfer of ideas across cultural, linguistic, and geographical borders (Streitwieser 2014). States, foundations, and international organisations have systematically increased educational exchange and mobility of scientists. These trends are more than symbolically significant, as border crossings transform individual careers, epistemic networks, and scientific capacity (Jöns 2018). Yet such opportunities remain highly-stratified not only by region, but also along class, gender, and ethnic boundaries, despite transnational 
higher education and mobility having witnessed tremendous growth (Zippel 2017). Academics continue to move consistent with long-established hierarchies among nationstates and organisations, yet academic stratification dimensions continuously evolve (Kim 2017). Such globalisation manifests itself in joint, dual, or franchised programmes, online and distance education, and international branch campuses, with research developing apace (see Kosmützky and Putty 2016). What will be the consequence of these elite border-crossings in the face of humanitarian crises of restricted migration and mobility, such as Europe's waves of refugees and newly-constructed walls between countries? Indeed, those responsible for governance of global, regional, and national systems face a crisis of legitimation that challenges higher education and science in their traditional means of generating expertise (Kennedy 2015).

Thus, amid calls for more 'relevance' and 'impact', the governance by and of science must address the age-old inequalities, new subjectivities, and the gaps between research, policies, and practices. Not only for scientists in countries experiencing rising nationalism, mobility is no luxury, but rather sustains academic life and autonomous thought. Fundamentally, in complex globe-spanning higher education and science systems, the diffusion of ideas and mobility of scholars is necessary for innovation and influence. Indeed, the strongest science systems are open: those with most international co-authorship and highest mobility rates among the research workforce; smaller countries, such as Switzerland and Singapore, excel (Wagner and Jonkers 2017). If the diverse languages of science pose a barrier to universal collaboration, academic, intellectual styles - not to mention personalities - go far beyond language to affect relative foci on paradigm-development, on description or explanation, and on commentary; all with varying modes of interaction (Galtung 1981). Such specificities will require far more than technologyassisted translation and will likely remain as crucial advantages of comparativists who have gained such knowledge through long-term investment in understanding other times and spaces. Team work and intellectual exchange will continue to demand intercultural openness, patience, and commitment. The basis for productive collaborative networks are the pre-existing relationships of the involved researchers and organisations, repeated interactions, and intellectual affinities (Ulnicane 2015).

Policymakers in the EU have indeed bolstered organisations to support such networks, whether in research or teaching, that fundamentally expand the potential for comparative education even as they facilitate further European integration (see Marques 2018). Researchers could analyze the organisational conditions for collaboration in multicultural teams and for an optimal sharing of expertise - minimizing misunderstandings and conflicts (Dusdal, Oberg, and Powell 2019). Among the drivers of collaborations across boundaries are professional associations operating on different levels, such as the Comparative Education Society in Europe (CESE), the Comparative International Education Society (CIES) or the World Council on Comparative Education Socities (WCCES), all providing platforms and fora for exchange and deliberation. These associations facilitate the field's development by numerous mechanisms, such as assuming responsibility for the editing, publication, and dissemination of the key publications of the field, i.e. CIES and the Comparative Education Review (see Epstein 2016). Finally, it is certainly not purely academic whether capacity-building for comparative social sciences is currently being curtailed, continues or is strengthened. Rather, comparisons as well as policy learning and coordination have become increasingly salient, albeit often a superficial use of indicators. 


\section{Comparisons, governance, evaluation, and supranational coordination}

The influence of internationally acknowledged ideas, norms, and standards ('best' or 'good' practices) manifests itself at various levels. Once change is acknowledged as desirable, policies are mediated by the politics of borrowing and lending. Systematic international and intercultural exchange enhances policy learning, in turn increasingly affected by global competition in education and labour markets. In some regions, supranational coordination further strengthens such diffusion. At the forefront of social and economic change and nation-state development, education and science systems foster and reflect major societal shifts even as they exhibit persistent cultural particularities. Learning from leaders has always been significant as countries compete for cultural and economic power. Yet global transformations have made the supranational level and cross-national comparisons even more significant, with regional embeddedness also substantial. The 'competition fetish' (Naidoo 2016) at various levels reflects individual scholars jockeying for scarce resources, from research funding to reputation; corporations entering the burgeoning private market for educational services; and states vying for 'excellence' in research. Universities distinguish themselves through sophisticated identity campaigns, competing for students and research funds via market placement in stratified higher education systems (Drori, Delmestri, and Oberg 2013).

Today, competitiveness is continuously monitored by comparative indicators used by policymakers, scholars, and administrators to generate reform goals, to identify standards and best practices, and to empirically verify policies and programmes. As ever, countries enact policies that emulate - or are legitimated by reference to - successful foreign models. Mechanisms of such cross-cultural transfer include 'continuous competitive comparison' in such forms as rankings, benchmarking, and best practices; policy learning and networks; and intergovernmental negotiation and supranational coordination. All of these unfold their positive and negative effects at the nexus of collaboration and competition.

For centuries, only a few regional centres of learning were highly influential, depending on economic and cultural power, as on linguistic dominance. Today, based on quantitative and qualitative indicators, universities in many countries compete worldwide for talent, funding, and prestige. If most universities have little chance of succeeding to become preeminent, overall the academic drift in higher education that combines teaching and research missions has resulted in rising credential levels and broadened science capacity. Scientific discovery is a global pursuit, as two hundred countries now contribute to scientific knowledge production in leading peer-reviewed journals (Powell et al. 2017). If 'perpetual comparison' both within and between countries creates winners and losers (Nóvoa and Yariv-Mashal 2003), more than ever universities and scientific communities are linked globally, via communication networks, conferences, and exchanges, answering competitive pressures with myriad forms of collaboration. With differences in influence depending on past colonial relationships, languages, and politics, leading countries in education and science worldwide, including Germany, the United States, and China, have differentially developed their higher education and science systems - and provide different levels of autonomy crucial for path-breaking fundamental research. Policymakers continue to look across borders for inspiration, guidance, or practices as they push reforms of education and science to sustain or increase their competitiveness without understanding the complexity and path dependence of system development. 
Supranational coordination facilitates the definition of standards, extends cross-border mobility, and supports collaboration. In education and science, the open method of coordination now stretches far beyond the EU in engaging countries in reform initiatives (Bologna process) and funding instruments (EU Framework Programme for Research and Innovation; currently: Horizon 2020; nearly €80 billion, 2014-2020). Through standardisation, mobility, and transparency, such coordination relies on a range of instruments to strengthen competitiveness. However, the costs of research have also risen and the expansion of scientific publication makes synthesis challenging. Simultaneously, evaluation and continuous measurement of outputs has displaced older input orientations of research policymaking. This risks short-termism antithetical to sustained devotion required for truly path-breaking research.

In an era of ubiquitous evaluation, R\&D governance is based on explicitly measured and evaluated outputs, mainly research articles, less the scholarly monographs that provide the in-depth contextualisation so crucial for fundamental research on education systems, cultures, and practices. Indeed, increased emphasis on research articles is an unintended consequence of research evaluation (Marques et al. 2017). The effects and changed behaviour of individuals and organisations in such regimes has garnered attention, yet few longitudinal studies uncover long-term trends in largely university-based research (but see Powell, Baker, and Fernandez [2017] 2019). Worldwide, research evaluation systems share the rationale of financial accounting that spreads and entrenches certain values and techniques that aim to foster enhanced performance and achieve efficiency in science (Whitley and Gläser 2007). Yet attempts to transform qualities into numeric forms to measure, compare, and inform decision-making reduce the quality of information. This threatens to narrow the recognition and impact of knowledge generated in diverse systems, especially as media companies convert peer review judgements into products to market for profit, such as higher education rankings (Marques et al. 2017; Marques and Powell 2019). Further discipline-specific studies are needed to emphasise how research evaluation impacts the structural organisation and cognitive development of research, reinforcing stratification and standardisation. Evaluation systems reflect the changing relationships between states and universities and other research organisations. The consequences of such new forms of governance are often intentional, yet many unanticipated or unintentional results also follow.

\section{Outlook}

Along with the unprecedented structural expansion of higher education globally that facilitates the 'knowledge society' (Baker 2014; Powell, Baker, and Fernandez [2017] 2019; Meyer and Frank 2020), the perceived importance of evidence-based policymaking and notions of quality, excellence, relevance, and impact have diffused (Zapp, Marques, and Powell 2018). Government-funded R\&D and research councils' substantial growth in both funding and large-scale, long-term planning, including thematic choices, are evidence of such 'programmification'. If the importance of comparison (in particular, of external models) has grown substantially in an era of transnationalization, translation and interpretation occur at each level of governance, often paradoxically, as in the 'special educationalization' of inclusion (Biermann 2018) or in the lack of institutional permeability between vocational education and training and higher 
education (Bernhard 2017) despite their hybridisation in dual studies (Graf 2013). This results in sustained diversity across societies as within institutions and organisations as implementation proceeds in systems developing path-dependently. Comparative education scholars study such diffusion of ideas, norms, and policies in an era of stark competition and simultaneously rising collaboration. While the technology-aided and mobility-facilitated potential for collaborations in quantitative, qualitative, and historical research has grown, the theoretical approaches and methological tools must be linked; a challenge for this field and all comparative social sciences. To coordinate complex comparative research projects requires organisational support, intercultural sensitivity, and tenacity.

Science and policymaking have become increasingly intertwined, resulting in new challenges of authority and conflicts over research priorities and output measurements. As Fenwick, Mangez, and Ozga (2014) argue, technological capacity is revolutionising the 'extensive system knowledge' available even as myriad comparisons increasingly legitimate education policies, programmes, and practices. Yet, such forces also displace contextualised, local understandings and meanings essential for system development. This increases the necessity to attend to the complexities of a dynamic relationship in which boundary-spanning managers gain influence as they translate across the divide of science and policy (Normand 2016). Not only are different conceptualizations of disciplinary research and development across countries and regions crucial to analyze, but also the distinct legacies thereof. The EU performs an expanding role in constructing a European Research Area, in establishing cross-border networks, and in shaping research agendas (Marques 2018; Zapp, Marques, and Powell 2018). This demonstrates how supranational governance simultaneously offers incentives and puts pressure on national and local actors to align their research to overarching priorities and themes - and to collaborate interculturally; a vital resource for sustained comparative social sciences and intercultural comparison within fields.

Over the past several decades, political interest in evidence-based policy-making, quality assessment, and research evaluation, and direct involvement of various decisionmakers has led to the establishment of new organisations, funding instruments, programmes, and training programmes. Often, such developments challenge old paradigms, disciplinary divisions of labour, and boundaries between science and policy. With technologies and politics facilitating but also hindering sustained collaboration essential to solve our most wexing global and local problems, comparative educationalists must continue to provide the sustantive knowledge of other structures, cultures, and practices of education. Acquired through sustained exposure and meaningful connections in other cultures, such knowledge is needed to counteract the reductionism typical of superficial comparisons proferred not only in the popular media. Policymakers and organisational actors often make highly selective use of comparative education knowledge stores. To counter such reductionism, in-depth historical and comparative studies of diffusion and learning as well as transfer and translation across the divides of academy, politics, and practice remain crucial. The field of comparative education must claim its relevance more persuasively, even as scholarly exchange, mobilities, and intercultural knowledge endure as the vital foundations of such research. 


\section{Acknowledgements}

I express deep gratitude to my mentors, collaborators, and students as well as to the organisations and foundations that have enabled my educational career and scholarly contributions.

\section{Disclosure statement}

No potential conflict of interest was reported by the author.

\section{Funding}

This work was supported by Université du Luxembourg [R-AGR-0221].

\section{Notes on the contributor}

Justin J. W. Powell has been Professor of Sociology of Education in the Institute of Education and Society at the University of Luxembourg since 2012. His comparative institutional analyses chart persistence and change in special and inclusive education, vocational training, higher education and science systems, and research policy. He holds a BA from Swarthmore College (USA), an MA from Humboldt-Universität zu Berlin, Germany, and a doctorate in sociology from the Freie Universität Berlin, Germany. Among diverse publications in English and German in educational and social science journals, his books include Soziale Ungleichheit. Klassische Texte zur Sozialstrukturanalyse (Campus Verlag, 2009; co-edited with H. Solga and P.A. Berger); Barriers to Inclusion: Special Education in the US and Germany (Routledge, 2011/2016; Irving K. Zola Award); Comparing Special Education: Origins to Contemporary Paradoxes (Stanford University Press, 2011; co-authored with J.G. Richardson; AERA Division B Outstanding Book Award); The Century of Science: The Global Triumph of the Research University (Emerald, 2017, co-edited with D.P. Baker and F. Fernandez; ASHE Award for Significant Research on International Higher Education); and European Educational Research (Re)Constructed: Institutional Change in Germany, the UK, Norway and the EU (Oxford: Symposium Books, 2018; co-authored with M. Zapp and M. Marques).

\section{ORCID}

Justin J. W. Powell (1) http://orcid.org/0000-0002-6567-6189

\section{References}

Adams, J. 2013. "Collaborations: The Fourth Age of Research." Nature 497 (7451): 557-560.

Aman, V., and A. Botte. 2017. "A Bibliometric View on the Internationalization of European Educational Research." European Educational Research Journal 16 (6): 843-868. doi:10.1177/ 1474904117729903.

Artiles, A. J., E. B. Kozleski, and F. R. Waitoller. 2015. Inclusive Education: Examining Equity on Five Continents. Cambridge, MA: Harvard Education Press.

Baker, D. P. 2014. The Schooled Society: The Educational Transformation of Global Culture. Stanford: Stanford University Press.

Beech, J. 2006. "The Theme of Educational Transfer in Comparative Education." Research in Comparative and International Education 1 (1): 2-13. doi:10.2304/rcie.2006.1.1.2.

Bernhard, N. 2017. Durch Europäisierung zu mehr Durchlässigkeit?. Opladen: Budrich UniPress.

Bhandari, R., and P. Blumenthal, eds. 2011. International Students and Global Mobility in Higher Education. Basingstoke: PalgraveMacmillan.

Biermann, J. 2018. Comparing Article 24 UN CRPD's Influence on Inclusive Education in Nigeria and Germany." Dissertation, Humboldt University of Berlin, Germany. 
Biermann, J., and J. J. W. Powell. 2014. "Institutionelle Dimensionen Inklusiver Schulbildung: Herausforderungen der UN-Behindertenrechtskonvention für Deutschland, Island und Schweden im Vergleich." Zeitschrift für Erziehungswissenschaften 17 (4): 679-700. doi:10.1007/ s11618-014-0588-0.

Blanck, J. M., B. Edelstein, and J. J. W. Powell. 2013. “Persistente schulische Segregation oder Wandel zur inklusiven Bildung?" Schweizerische Zeitschrift für Soziologie = Revue Suisse de Sociologie 39 (5): 267-292.

Brankovic, J., L. Ringel, and T. Werron. 2018. "How Rankings Produce Competition: The Case of Global University Rankings." Zeitschrift für Soziologie 47 (4): 270-288. doi:10.1515/zfsoz-2018-0118.

Bromley, P., and J. W. Meyer. 2015. Hyper-Organization. Oxford: Oxford University Press.

Campbell, J. L., and O. K. Pedersen. 2014. The National Origins of Policy Ideas. Princeton, NJ: Princeton University Press.

Clark, B. R. 1970. The Distinctive College: Antioch, Reed, and Swarthmore. Chicago: Aldine.

Cook, B., S. Hite, and E. Epstein. 2004. "Discerning Trends, Contours, and Boundaries in Comparative Education: A Survey of Comparativists and Their Literature." Comparative Education Review 48 (2): 123-149. doi:10.1086/382619.

Cowen, R. 2009. "The Transfer, Translation and Transformation of Educational Processes: And Their Shape-shifting?" Comparative Education 45 (3): 315-327.

Cummings, W. 1999. "The InstitutionS of Education: Compare, Compare, Compare!" Comparative Education Review 43 (4): 413-437.

Czarniawska, B., and B. Joerges. 1996. "Travels of Ideas." In Translating Organizational Change, edited by B. Czarniawska, and G. Sevon, 13-48. Berlin: de Gruyter.

Dakowska, D. 2019. "Higher Education Policy in the European Union." Oxford Research Encyclopedia of Politics. doi:10.1093/acrefore/9780190228637.013.1480.

Dale, R., and S. Robertson, eds. 2009. Globalisation and Europeanisation in Education. Oxford: Symposium Books.

DiMaggio, P. J., and W. W. Powell. 1983. "The Iron Cage Revisited: Institutional Isomorphism and Collective Rationality in Organizational Fields." American Sociological Review 48 (2): 147-160. doi:10.2307/2095101.

Dobbin, F., B. Simmons, and G. Garrett. 2007. "The Global Diffusion of Public Policies: Social Construction, Coercion, Competition, or Learning?" Annual Review of Sociology 33 (1): 449-472. doi:10.1146/annurev.soc.33.090106.142507.

Dobbins, M., and C. Knill. 2014. Higher Education Governance and Policy Change in Western Europe. Basingstoke: PalgraveMacmillan.

Drori, G. S., G. Delmestri, and A. Oberg. 2013. "Branding the University." In Trust in Higher Education Institutions, edited by L. Engwall, and P. Scott, 134-147. London: Portland Press.

Drori, G. S., J. W. Meyer, F. O. Ramirez, and E. Schofer. 2003. Science in the Modern World Polity. Stanford: Stanford University Press.

Dusdal, J. 2018. Welche Organisationsformen produzieren Wissenschaft? Frankfurt/Main, Germany: Campus.

Dusdal, J., A. Oberg, and J. J. W. Powell. 2019. “Das Verhältnis zwischen Hochschule und Wissenschaft in Deutschland." In Komplexe Dynamiken globaler und lokaler Entwicklungen, edited by N. Burzan, 1-13. Göttingen: Deutsche Gesellschaft für Soziologie (DGS). https://publikationen.soziologie.de/ index.php/kongressband_2018/article/view/1109.

Dusdal, J., J. J. W. Powell, D. P. Baker, Y.-C. Fu, Y. Shamekhi, and M. Stock. in press. University vs. Researchlnstitute? The Dual Pillars of German Science Production 1950-2010. Minerva.

Epstein, E. H., ed. 2016. Crafting a Global Field: Six Decades of the Comparative and International Education Society. Hong Kong: Comparative Education Research Centre, University of Hong Kong.

Espeland, W. N., and M. Sauder. 2016. Engines of Anxiety: Academic Rankings, Reputation, and Accountability. New York: Russell Sage Foundation.

Fenwick, T., E. Mangez, and J. Ozga. 2014. Governing Knowledge: Comparison, Knowledge-Based Technologies and Expertise in the Regulation of Education (World Yearbook of Education). London: Routledge.

Fleck, C. 2011. A Transatlantic History of the Social Sciences. London: Bloomsbury. 
Frank, D. J., and J. W. Meyer. 2020, in press. The University and the Global Knowledge Society. Princeton, NJ: Princeton University Press.

Galtung, J. 1981. "Structure, Culture, and Intellectual Style: An Essay Comparing Saxonic, Teutonic, Gallic and Nipponic Approaches." Social Science Information 20 (6): 817-856. doi:10.1177/ 053901848102000601.

Gonon, P. 1998. Das internationale Argument in der Bildungsreform. Berne: Peter Lang.

Gorur, R., S. Sellar, and G. Steiner-Khamsi, eds. 2019. Comparative Methodology in the Era of Big Data and Global Networks (World Yearbook of Education). Abingdon: Routledge.

Graf, L. 2013. The Hybridization of Vocational Training and Higher Education in Austria, Germany and Switzerland. Opladen, Germany: Budrich UniPress.

Graf, L., and J. J. W. Powell. 2017. "How Employer Interests and Investments Shape Advanced Skill Formation in Higher Education." PS: Political Science and Politics 50 (2): 418-422. doi:10.1017/ S1049096516002936.

Günes, E., M. T. Üstündag, H. Yalçn, and M. Safran. 2017. "Investigating Educational Research Articles (1980-2014) in Terms of Bibliometric Indicators." International Online Journal of Educational Sciences 9 (1): 101-117.

Hadjar, A., and C. Gross, eds. 2016. Education Systems and Inequalities: International Comparisons. Bristol: Policy Press.

Harmsen, R., and J. J. W. Powell. 2018. "Higher Education Systems and Institutions Luxembourg." In Encyclopedia of International Higher Education Systems and Institutions, edited by J. C. Shin and P. Teixeira, 1-5. Heidelberg: Springer. doi:10.1007/978-94-017-9553-1.

Hartong, S. 2019. "The Transformation of State Monitoring Systems in Germany and the US." In Researching the Global Education Industry, edited by M. Parreira do Amaral, G. Steiner-Khamsi, and Ch. Thompson, 157-180. Basingstoke: PalgraveMacmillan.

Hasse, R., and G. Krücken. 2013. "Competition and Actorhood: A Further Expansion of the NeoInstitutional Agenda." Sociologia Internationalis 51 (2): 181-205. doi:10.3790/sint.51.2.181.

Hollstein, B., W. Matiaske, and K.-U. Schnapp, eds. 2017. Networked Governance: New Research Perspectives. Heidelberg: Springer.

Jöns, H. 2018. "Boundary-crossing Academic Mobilities in Glocal Knowledge Economies: New Research Agendas Based on Triadic Thought." Globalisation Societies and Education 16 (2): 151161. doi:10.1080/14767724.2017.1413977.

Kamola, I. A. 2019. Making the World Global: US Universities and the Production of the Global Imaginary. Durham, NC: Duke University Press.

Kennedy, M. D. 2015. Globalizing Knowledge: Intellectuals, Universities, and Publics in Transformation. Stanford, CA: Stanford University Press.

Kim, T. 2017. "Academic Mobility Transnational Identity Capital and Stratification Under Conditions of Academic Capitalism." Higher Education 73 (6): 981-997. doi:10.1007/s10734-017-0118-0.

Kmiotek-Meier, E., U. Karl, and J. J. W. Powell. 2018. "The Centrality of International Student Mobility in Luxembourg's Higher Education Policy Discourse." Higher Education Policy 31. online first. doi:10. 1057/s41307-018-0118-4.

Komatsu, H., and J. Rappleye. 2017. "A New Global Policy Regime Founded on Invalid Statistics? Hanushek, Woessmann, PISA, and Economic Growth." Comparative Education 53 (2): 166-191. doi:10.1080/03050068.2017.1300008.

Kosmützky, A. 2018. "A Two-Sided Medal: On the Complexity of International Comparative and Collaborative Team Research." Higher Education Quarterly 72 (4): 314-331. doi:10.1111/hequ. 12156.

Kosmützky, A., and R. Putty. 2016. "Transcending Borders and Traversing Boundaries: A Systematic Review of the Literature on Transnational, Offshore, Cross-Border, and Borderless Higher Education." Journal of Studies in International Education 20 (1): 8-33. doi:10.1111/hequ.12156.

Kurzman, C. 2017. "Scholarly Attention and the Limited Internationalization of US Social Science." International Sociology 32 (6): 775-795. doi:10.1177/0268580917729991.

Lamont, M. 2009. How Professors Think: Inside the Curious World of Academic Judgment. Cambridge, MA: Harvard University Press. 
Lawn, M., and S. Grek. 2012. Europeanizing Education: Governing a New Policy Space. Oxford: Symposium Books.

Leahey, E. 2016. "From Sole Investigator to Team Scientist: Trends in the Practice and Study of Research Collaboration." Annual Review of Sociology 42: 81-100. doi:10.1146/annurev-soc081715-074219.

Leydesdorff, L., and H. Etzkowitz. 1998. "The Triple Helix as a Model for Innovation Studies." Science and Public Policy 25 (3): 195-203. doi:10.1093/spp/25.3.195.

Mahoney, J., and D. Rueschemeyer, eds. 2003. Comparative Historical Analysis in the Social Sciences. New York: Cambridge University Press.

Mahoney, J., and K. Thelen, eds. 2010. Explaining Institutional Change. Cambridge: Cambridge University Press.

Mahoney, J., and K. Thelen, eds. 2015. Advances in Comparative-Historical Analysis. New York: Cambridge University Press.

Manson, M. 2018. "Origins and Traditions in Comparative Education: Challenging Some Assumptions." Comparative Education 54 (1): 1-9. doi:10.1080/03050068.2017.1416820.

Margue, M., ed. 2013. Université du Luxembourg 2003-2013. Luxembourg: University of Luxembourg.

Marques, M. 2018. "Research Governance through Public Funding Instruments: Institutional Change in Educational Research in the European Union and England (1984-2014)." Dissertation, University of Luxembourg.

Marques, M., and J. J. W. Powell. 2019. "Ratings, Rankings, Research Evaluation: How do Schools of Education Behave Strategically Within Stratified UK Higher Education?" Higher Education, doi:10. 1007/s10734-019-00440-1.

Marques, M., J. J. W. Powell, M. Zapp, and G. Biesta. 2017. “How Does Research Evaluation Impact Educational Research? Exploring Intended and Unintended Consequences of Research Assessment in the United Kingdom, 1986-2014." European Educational Research Journal 16 (6): 820-842. doi:10.1177/1474904117730159.

Martens, K., D. Niemann, and J. Teltemann. 2016. "Effects of International Assessments in Education A Multidisciplinary Review." European Educational Research Journal 15 (5): 516-522. doi:10.1177/ 1474904116668886.

McLeod, J., N. W. Sobe, and T. Seddon, eds. 2018. Uneven Space-Times of Education: Historical Sociologies of Concepts, Methods, and Practices (World Yearbook of Education). Abingdon: Routledge.

Meyer, M. B. 2008. "The Dynamics of Science in a Small Country: The Case of Luxembourg." Science and Public Policy 35 (5): 361-371. doi:10.3152/030234208X317133.

Meyer, J. W., J. Boli, G. Thomas, and F. O. Ramirez. 1997. "World Society and the Nation-State." American Journal of Sociology 103 (1): 144-181.

Meyer, J. W., and F. O. Ramirez. 2007. "The World Institutionalization of Education." In Weltkultur und kulturelle Bedeutungswelten, edited by J. Schriewer, 279-297. Frankfurt/Main: Peter Lang.

Mosbah-Natanson, S., and Y. Gingras. 2014. "The Globalization of Social Sciences? Evidence From a Quantitative Analysis of 30 Years of Production, Collaboration and Citations in the Social Sciences (1980-2009)." Current Sociology 62 (5): 626-646. doi:10.1177/0011392113498866.

Naidoo, R. 2016. "The Competition Fetish in Higher Education: Varieties, Animators and Consequences." British Journal of Sociology of Education 37 (1): 1-10. doi:10.1080/01425692. 2015.1116209.

Normand, R. 2016. The Changing Epistemic Governance of European Education. Cham: Springer. doi:10. 1007/978-3-319-31776-2.

Nóvoa, A., and T. Yariv-Mashal. 2003. “Comparative Research in Education: A Mode of Governance or a Historical Journey?" Comparative Education 39 (4): 423-438. doi:10.1080/0305006032000162002.

Ortiga, Y. Y., M. Chou, G. Sondhi, and J. Wang. 2019. "Working Within the Aspiring Center: Professional Status and Mobilities among Migrant Faculty in Singapore." Higher Education Policy 32 (2): 149166. doi:10.1057/s41307-017-0078-0.

Parreira do Amaral, M., G. Steiner-Khamsi, and C. Thompson, eds. 2019. Researching the Global Education Industry. Basingstoke: PalgraveMacmillan. 
Phillips, D. 2011. The German Example: English Interest in Educational Provision in Germany Since 1800. London: Continuum.

Powell, J. J. W. 2009. "To Segregate or to Separate? Special Education Expansion and Divergence in the United States and Germany." Comparative Education Review 53 (2): 161-187. doi:10.1086/ 597816.

Powell, J. J. W. 2013. "Founding the Inter/National University of Luxembourg in the Bologna Era." In Université du Luxembourg 2003-2013, edited by M. Margue, 22-27. Luxembourg: University of Luxembourg.

Powell, J. J. W. 2014. "International National Universities: Migration and Mobility in Luxembourg and Qatar." In Internationalisation of Higher Education and Global Mobility, edited by B. Streitwieser, 119-133. Oxford: Symposium Books.

Powell, M. M. W. 2018. Living at the Heart of the UVA Community: Alderman Library, Madison House, Theta Chi \& Beyond. Charlottesville, VA: KDP.

Powell, J. J. W. [2011] 2016. Barriers to Inclusion: Special Education in the United States and Germany. Abingdon: Routledge.

Powell, J. J. W., D. P. Baker, and F. Fernandez, eds. (2017) 2019. The Century of Science: The Global Triumph of the Research. IPES vol. 33. Bingley: Emerald.

Powell, J. J. W., N. Bernhard, and L. Graf. 2012. “The Emergent European Model in Skill Formation: Comparing Higher Education and Vocational Training in the Bologna and Copenhagen Processes." Sociology of Education 85 (3): 240-258. doi:10.1177/0038040711427313.

Powell, J. J. W., and J. Dusdal. 2017a. "Science Production in Germany, France, Belgium, and Luxembourg: Comparing the Contributions of Research Universities and Institutes to Science, Technology, Engineering, Mathematics, and Health." Minerva 55: 413-434. doi:10.1007/s11024017-9327-z.

Powell, J. J. W., and J. Dusdal. 2017b. “The European Center of Science Productivity: Research Universities and Institutes in France, Germany, and the United Kingdom." In The Century of Science, edited by J. J. W. Powell, D. P. Baker, and F. Fernandez, 55-84. Bingley: Emerald.

Powell, J. J. W., F. Fernandez, J. T. Crist, J. Dusdal, L. Zhang, and D. P. Baker. 2017. “Introduction." In The Century of Science, edited by J. J. W. Powell, D. P. Baker, and F. Fernandez, 1-36. Bingley: Emerald.

Powell, J. J. W., and C. Finger. 2013. "The Bologna Process's Model of Mobility in Europe: The Relationship of its Spatial and Social Dimensions." European Educational Research Journal 12 (2): 270-285. doi:10.2304/eerj.2013.12.2.270.

Powell, J. J. W., L. Graf, N. Bernhard, L. Coutrot, and A. Kieffer. 2012. "The Shifting Relationship between Vocational and Higher Education in France and Germany: Towards Convergence?" European Journal of Education 47 (3): 405-423. doi:10.1111/j.1465-3435.2012.01534.x.

Powell, J. J. W., and H. Solga. 2010. "Analyzing the Nexus of Higher Education and Vocational Training in Europe: A Comparative-Institutional Framework." Studies in Higher Education 35 (6): 705-721. doi:10.1080/03075070903295829.

Powell, J. J. W., and H. Solga. 2011. "Why Are Higher Education Participation Rates in Germany so Low? Institutional Barriers to Higher Education Expansion." Journal of Education and Work 24 (1-2): 49-68. doi:10.1080/13639080.2010.534445.

Powell, J. J. W., and C. Trampusch. 2012. "Europeanization and the Varying Responses in Collective Skill Systems." In The Political Economy of Collective Skill Systems, edited by M. R. Busemeyer and C. Trampusch, 284-313. Oxford: Oxford University Press.

Powell, J. J. W., M. Zapp, M. Marques, and G. Biesta. 2018. "(Re)Constructing Institutional Change in European Educational Research." In European Educational Research (Re)Constructed, edited by M. Zapp, M. Marques, and J. J. W. Powell, 7-23.

Richardson, J. G., and J. J. W. Powell. 2011. Comparing Special Education: Origins to Contemporary Paradoxes. Stanford, CA: Stanford University Press.https://www.sup.org/books/title/?id=16954.

Sahlin-Andersson, K. 1996. "Imitating by Editing Success: The Construction of Organizational Fields." In Translating Organizational Change, edited by B. Czarniawska, and G. Sevón, 69-92. Berlin: de Gruyter.

Schmidt, V. A. 2008. "Discursive Institutionalism: The Explanatory Power of Ideas and Discourse." Annual Review of Political Science 11: 303-326. doi:10.1146/annurev.polisci.11.060606.135342. 
Schneiberg, M., and E. S. Clemens. 2006. "The Typical Tools for the Job: Research Strategies in Institutional Analysis." Sociological Theory 24 (3): 195-227. doi:10.1111/j.1467-9558.2006.00288.x.

Schofer, E., and J. W. Meyer. 2005. "The Worldwide Expansion of Higher Education in the Twentieth Century." American Sociological Review 70 (6): 898-920. doi:10.1177/000312240507000602.

Schriewer, J. 2006. "Comparative Social Science: Characteristic Problems and Changing Problem Solutions." Comparative Education 42 (3): 299-336. doi:10.1080/03050060601022640.

Schriewer, J., ed. 2012. Re-Conceptualising the Global/Local Nexus, Special Issue of Comparative Education 48 (4): 411-543.

Schriewer, J., ed. 2016. World Culture Re-Contextualised. Abingdon: Routledge.

Scott, W. R. 2014. Institutions and Organizations. Thousand Oaks, CA: SAGE.

Solga, H. 2005. Ohne Abschluss in die Bildungsgesellschaft. Die Erwerbschancen gering qualifizierter Personen aus soziologischer und ökonomischer Perspektive. Opladen: Verlag Barbara Budrich.

Steiner-Khamsi, G. and F. Waldow, eds. 2012. Policy Borrowing and Lending (World Yearbook of Education). London: Routledge.

Stevens, M. L., C. Miller-Idriss, and S. Shami. 2018. Seeing the World: How US Universities Make Knowledge in a Global Era. Princeton: Princeton University Press.

Streitwieser, B., ed. 2014. Internationalization of Higher Education and Global Mobility. Oxford: Symposium Books.

Streitwieser, B., and G. Light. 2018. "Student Conceptions of International Experience in the Study Abroad Context." Higher Education 75 (3): 471-487. doi:10.1007/s10734-017-0150-0.

Suárez, D., and P. Bromley. 2016. "Institutional Theories and Levels of Analysis." In World Culture ReContextualised, edited by J. Schriewer, 139-159. London: Routledge.

Sugimoto, C. R., et al. 2017. "Scientists Have Most Impact When They're Free to Move." Nature 550 (5 October 2017): 29-31.

Takayama, K. 2018. "Beyond Comforting Histories: The Colonial/Imperial Entanglements of the International Institute Paul Monroe and Isaac L. Kandel at Teachers College Columbia University." Comparative Education Review 62 (4): 459-481. doi:10.1086/699924.

Ulnicane, I. 2015. "Why do International Research Collaborations Last? Virtuous Circle of Feedback Loops, Continuity and Renewal." Science and Public Policy 42 (4): 433-447. doi:10.1093/scipol/ scu060.

Unterhalter, E. 2017. "Negative Capability? Measuring the Unmeasurable in Education." Comparative Education 53 (1): 1-16. doi:10.1080/03050068.2017.1254945.

Van Mol, C. 2014. Intra-European Student Mobility in International Higher Education Circuits. Basingstoke: PalgraveMacmillan.

Wagner, C. S. 2005. "Six Case Studies of International Collaboration in Science." Scientometrics 62 (1): 3-26. doi:10.1007/s11192-005-0001-0.

Wagner, C. S., and K. Jonkers. 2017. "Open Countries Have Strong Science." Nature 550 (5 October 2017): 32-33.

Werron, T. 2015. "Why do we Believe in Competition? A Historical-Sociological View of Competition as an Institutionalized Modern Imaginary" Distinktion: Journal of Social Theory 16 (2): 186-210. doi:10.1080/1600910X.2015.1049190.

Whitley, R., and J. Gläser. 2007. "Changing Governance of the Public Sciences." In The Changing Governance of the Sciences, edited by R. Whitley, and J. Gläser, 3-27. Heidelberg, Germany: Springer.

Zapp, M., M. Marques, and J. J. W. Powell. 2018. European Educational Research (Re)Constructed: Institutional Change in Germany, the United Kingdom, Norway and the European Union. Oxford: Symposium Books.

Zapp, M., and J. J. W. Powell. 2016. "How to Construct an Organizational Field: Empirical Educational Research in Germany, 1995-2015." European Educational Research Journal 15 (5): 537-557. doi:10. $1177 / 1474904116641422$.

Zapp, M., and J. J. W. Powell. 2017. "Moving Towards Mode 2? Evidence-Based Policy-Making and the Changing Conditions for Educational Research in Germany." Science and Public Policy 44 (5): 645655. doi:10.1093/scipol/scw091. 
Zapp, M., and F. O. Ramirez. 2019. “Beyond Internationalisation and Isomorphism - The Construction of a Global Higher Education Regime." Comparative Education. doi:10.1080/03050068.2019. 1638103.

Zhang, L., J. J. W. Powell, and D. P. Baker. 2015. "Exponential Growth and the Shifting Global Center of Gravity of Science Production, 1900-2011." Change: The Magazine of Higher Learning 47 (4): 46-49. doi:10.1080/00091383.2015.1053777.

Zippel, K. 2017. Women in Global Science. Stanford: Stanford University Press. 